\title{
Intensifikasi Lahan Melalui Sistem Pertanian Terpadu: Sebuah Tinjauan
}

\author{
Filya Hidayati*, Yonariza, Nofialdi, Dwi Yuzaria \\ Universitas Andalas \\ * filya.hidayati@yahoo.com
}

\begin{abstract}
Abstrak. Tinjauan ini bertujuan untuk melihat dan mengumpulkan informasi tentang potensi lahan yang belum termanfaatkan secara optimal pada penerapan sistem pertanian terpadu. Intensifikasi pertanian yang merupakan pengolahan lahan pertanian yang ada dengan sebaik-baiknya untuk meningkatkan hasil pertanian dengan menggunakan berbagai sarana. Meningkatkan efisiensi penggunaan lahan, khususnya menjaga kesuburan lahan. Sistem pertanian berkelanjutan adalah kembali kepada alam, yaitu sistem pertanian yang tidak merusak, tidak mengubah, serasi, selaras dan seimbang dengan lingkungan atau pertanian yang patuh dan tunduk pada kaidah-kaidah alamiah sehingga akan dapat diwujudkan suatu sistem pertanian yang berkelanjutan. Tulisan ini menggunakan kajian studi kepustakaan pada jurnal-jurnal terkait dengan lahan pada sistem pertanian terpadu dengan mencari kesamaan, perbedaan, memberikan pandangan, serta meringkas hasil penelitian terdahulu guna mencapai tujuan tulisan ini. Tulisan ini mencakup studi kepustakaan pada perkembangan dan penggunaan lahan yang terjadi pada sistem pertanian terpadu pada daerah-daearah pertanian dengan lahan yang luas di indonesia pada saat dulu dan sekarang. Dari studi kepustakaan ini di dapatkan hasil bahwa dengan mengintesifkan penggunaaan lahan pada sistem pertanian terpadu bisa meningkatkan ketahanan pangan, kesejahteraan petani, meningkatkan lapangan pekerjaan, penciptaan teknologi terbarukan, dan pentingnya dukungan pemerintah terkait untuk terciptanya peluang bagi petani dalam meningkatkan skala pertaniannya serta meningkatkan kesuburan tanah sehingga pertanian berkelanjutan dapat terjadi dan lebih mensejahterakan petani dimasa yang akan datang.
\end{abstract}

Kata Kunci: lahan, sistem pertanian terpadu

\section{PENDAHULUAN}

Lahan diartikan sebagai lingkungan fisik yang terdiri atas lingkungan, relief, tanah, air dan vegetasi serta benda yang diatasnya sepanjang ada pengaruhnya terhadap penggunaan lahan, termasuk didalamnya hasil kegiatan manusian di masa lalu dan sekarang seperti hasil reklamasi laut, pembersihan vegetasi dan juga hasil yang merugikan seperti yang tersalinasi (Arsyad, 1989). Satu daerah dipermukaan bumi dengan sifatsifat tertentu yang meliputi biosfer, atmosfer, tanah, lapisan geologi, hidrologi, populasi tanaman dan hewan serta hasil kegiatan manusia di masa lalu dan sekarang, sampai pada tingkat tertentu dengan sifat-sifat tersebut mempunyai pengaruh yang berarti terhadap fungsi lahan oleh manusia pada masa sekarang dan masa yang akan datang (Sitorus, 2004).

Berdasarkan hasil kajian Badan Penelitian dan Pengembangan Pertanian, (2007), yang utamanya didasarkan pada hasil pemetaan sumberdaya lahan tingkat tinjau, dari total daratan Indonesia seluas 188,2 juta ha, lahan yang berpotensi atau sesuai untuk pertanian seluas 94 juta ha, yaitu 25,4 juta ha untuk pertanian lahan basah (sawah) dan 68,6 juta ha untuk pertanian lahan kering (Tabel 2). Lahan basah adalah lahan-lahan yang secara biofisik sesuai untuk pengembangan lahan sawah, meliputi lahan sawah yang saat ini ada, lahan rawa, maupun lahan non rawa yang memungkinkan untuk digenangi atau diirigasi. Lahan basah yang sesuai untuk lahan sawah seluas 25,4 juta ha, terluas terdapat di Papua (7,4 juta ha), kemudian yang lainnya terdapat di Kalimantan Tengah (2,3 juta ha), Kalimantan Barat (1,8 juta ha), Jawa Tengah (1,6 juta ha), Jawa Timur (1,5 juta ha), Riau (1,1 juta ha), dan provinsi lainnya di bawah 1 juta ha. Lahan kering didefinisikan sebagai hamparan lahan yang tidak pernah tergenang atau digenangi air pada sebagian besar waktu dalam setahun atau sepanjang waktu (Hidayat \& Mulyani, 2002). Lahan kering yang berpotensi atau sesuai untuk pertanian seluas 68,64 juta ha, yaitu 25,09 juta ha untuk tanaman semusim dan 43,55 juta ha untuk tanaman tahunan. Lahan kering yang sesuai untuk tanaman semusim seluas 25,09 juta ha, terluas

To cite this article: Hidayati, F., Yonariza, Nofialdi, dan D. Yuzaria. 2019. Intensifikasi Lahan Melalui Sistem Pertanian Terpadu: Sebuah Tinjauan. Unri Conference Series: Agriculture and Food Security 1: 113-119. https://doi.org/10.31258/unricsagr.1a15 
terdapat di Kalimantan Timur (5,5 juta ha), kemudian yang lainnya terdapat di Papua (4,2 juta ha), Sumatera Utara (2,8 juta ha), Sumatera Selatan (1,6 juta ha), Kalimantan Barat (1,7 juta ha), Lampung (1,3 juta ha), dan provinsi lainnya di bawah 1 juta ha. Lahan kering yang yang berpotensi atau sesuai untuk tanaman tahunan/perkebunan seluas 43,55 juta ha, dimana yang terluas terdapat di Papua (5,76 juta ha), kemudian yang lainnya terdapat di Kalimantan Tengah (4,7 juta ha), Kalimantan Barat (4,5 juta ha), Riau (4,27 juta ha), Kalimantan Timur (3,6 juta ha), Jambi (2,3 juta ha), Sumatera Selatan (2,2 juta ha), dan provinsi lainnya di bawah 1,5 juta ha. Lahan yang berpotensi untuk pertanian tersebut sebagian besar berada di dataran rendah $(<700 \mathrm{~m} \mathrm{dpl})$, yaitu seluas 87,2 juta ha $(92,7 \%)$, sedangkan sisanya 6,8 juta ha $(7,3 \%)$ berada di dataran tinggi (> $700 \mathrm{~m}$ dpl. Sedangkan berdasarkan ekosistem, lahan yang sesuai untuk pertanian tersebut berada pada kawasan rawa seluas 7,9 juta ha $(8,4 \%)$ dan kawasan non rawa seluas 86,2 juta ha $(91,6 \%)$ (Balai Besar Penelitian dan Pengembangan, 2008).

Tabel 1. Luas wilayah Indonesia yang telah dipetakan sumberdaya lahan/tanahnya pada berbagai tingkat pemetaan sampai dengan tahun 2010

\begin{tabular}{|c|c|c|c|c|c|c|c|c|}
\hline \multirow[t]{2}{*}{ Pulau } & & \multirow[t]{2}{*}{ Eksplorasi } & \multicolumn{2}{|c|}{ Tinjau } & \multicolumn{2}{|c|}{$\begin{array}{c}\text { Tinjau } \\
\text { mendalam }\end{array}$} & \multicolumn{2}{|c|}{$\begin{array}{c}\text { Semi detail dan } \\
\text { detail }\end{array}$} \\
\hline & & & .... 1.000 & ha ........ & & & & \\
\hline Sumatera & & 47.241 & 47.241 & $(100 \%)$ & 2.227 & $(5 \%)$ & 4.056 & $(8,6 \%)$ \\
\hline Jawa, Madura & & 13.21 & 13.21 & $(100 \%)$ & 2.715 & $(21 \%)$ & 4.401 & $(33,3 \%)$ \\
\hline Jumlah & & $\begin{array}{c}60.451 \\
(100 \%)\end{array}$ & 60.451 & $(100 \%)$ & 4.942 & $(8,18 \%)$ & 8.457 & $(14 \%)$ \\
\hline Nusa Tenggara & & 7.209 & 5.34 & $(74 \%)$ & 12 & $(0,2 \%)$ & 1.172 & $(16,3 \%)$ \\
\hline Kalimantan & & 52.89 & 38.53 & $(73 \%)$ & 891 & $(1,7 \%)$ & 9.072 & $(17,5 \%)$ \\
\hline Sulawesi & & 18.743 & 12.904 & $(69 \%)$ & 1.003 & $(5,4 \%)$ & 2.1 & $(11,2 \%)$ \\
\hline Maluku & & 7.817 & 800 & $(10 \%)$ & 55 & $(0,7 \%)$ & 499 & $(6,4 \%)$ \\
\hline Papua & & 41.105 & 4.016 & $(10 \%)$ & 684 & $(1,7 \%)$ & 2.176 & $(5,3 \%)$ \\
\hline Jumlah & & $\begin{array}{r}127.764 \\
(100 \%)\end{array}$ & 61.590 & $(48 \%)$ & 2.645 & $(2,1 \%)$ & 15.019 & $(11,8 \%)$ \\
\hline Total luas Indonesia & 188.215 & $\begin{array}{r}188.215 \\
(100 \%)\end{array}$ & $\begin{array}{l}122.041 \\
(64,8 \%)\end{array}$ & & & $\begin{array}{r}7.587 \\
(4,0 \%) \\
\end{array}$ & 36.776 & $(19,5 \%)$ \\
\hline
\end{tabular}

Sumber: Hikmatullah dan Hidayat (2007), diolah dan diperbaharui hingga tahun 2010

Tabel 2. Total luas lahan di Indonesia yang berpotensi atau sesuai untuk pertanian

\begin{tabular}{|c|c|c|c|c|}
\hline Pulau & $\begin{array}{c}\text { Pertanian lahan basah } \\
\text { Semusim }\end{array}$ & $\begin{array}{c}\text { Pertanian lahan kering } \\
\text { semusim*) }\end{array}$ & $\begin{array}{c}\text { Pertanian lahan kering } \\
\text { tahunan**) }\end{array}$ & Total \\
\hline \multicolumn{5}{|c|}{..................... ha } \\
\hline Sumatera & 5.187 .909 & 7.747 .637 & 13.182 .265 & 26.117.811 \\
\hline Jawa & 4.366 .736 & 1.964 .103 & 2.774 .498 & 9.105 .337 \\
\hline Bali dan NT & 479.829 & 1.229 .525 & 1.630 .891 & 3.340 .245 \\
\hline Kalimantan & 5.416 .543 & 8.953 .235 & 13.668 .043 & 28.037 .821 \\
\hline Sulawesi & 1.930 .187 & 790.983 & 3.787 .147 & 6.508 .317 \\
\hline $\begin{array}{l}\text { Maluku dan } \\
\text { Papua }\end{array}$ & 8.040 .334 & 4.403 .412 & 8.516 .790 & 20.960 .536 \\
\hline Indonesia & 25.421 .538 & 25.088 .895 & 43.559 .634 & 94.070 .067 \\
\hline
\end{tabular}

Sumber: Balai Besar Penelitian dan Pengembangan (2008), disederhanakan

\section{Lahan Pertanian}

Lahan pertanian merupakan lahan yang diperuntukan untuk kegiatan pertanian. Sumberdaya lahan pertanian memiliki banyak manfaat bagi manusia. Menurut (Sumaryanto \& Tahlim, 2005) menyebutkan bahwa manfaat lahan pertanian dapat dibagi menjadi dua kategori. Pertama, use values atau nilai penggunaan dapat pula disebut sebagai personal use values. Manfaat ini dihasilkan dari hasil eksploitasi atau kegiatan usahatani yang dilakukan pada sumber daya lahan pertanian. Kedua, non use values dapat pula disebut sebagai intrinsic values atau manfaat bawaan. Berbagai manfaat yang tercipta dengan sendirinya walaupun bukan merupakan tujuan dari kegiatan eksploitasi dari pemilik lahan pertanian termasuk dalam kategori ini. Salah satu lahan pertanian yang banyak terdapat di Indonesia khusunya Pulau Jawa adalah lahan sawah. Lahan sawah adalah suatu tipe penggunaan lahan yang untuk pengelolaannya memerlukan genangan air. Oleh karena itu, lahan sawah selalu memiliki permukaan datar atau yang didatarkan dan dibatasi oleh pematang untuk menahan air genangan (Puslittanak, 2003) (Pusat Penelitian dan Pengembangan Tanah dan Agroklimat 2003). Menurut Yoshida (1994) dan Kenkyu (1996) dalam Sumaryanto et al. (2005) bahwa dari aspek lingkungan, 
keberadaan lahan pertanian dapat berkontribusi dalam lima manfaat, yaitu: pencegahan banjir, pengendali keseimbangan tata air, pencegahan erosi, pengurangan pencemaran lingkungan yang berasal dari limbah rumah tangga, dan mencegah pencemaran udara yang berasal dari gas buangan.

Alih Fungsi Lahan pertanian Alih fungsi lahan pertanian bukan merupakan hal yang baru. Dengan semakin meningkatnya taraf hidup dan terbukanya kesempatan untuk menciptakan peluang kerja, yang ditandai oleh semakin banyaknya investor ataupun masyarakat dan pemerintah dalam melakukan pembangunan, maka semakin meningkat pula kebutuhan akan lahan. Dipihak lain jumlah lahan yang terbatas sehingga menimbulkan penggunaan lahan yang seharusnya beralih ke penggunaan non-pertanian. Alih fungsi lahan pertanian ke non-pertanian merupakan isu yang perlu diperhatikan karena ketergatungan masyarakat terhadap sektor pertanian.

Konversi lahan atau alih fungsi lahan adalah berubahnya satu penggunaan lahan ke penggunaan lainnya, sehingga permasalahan yang timbul akibat konversi lahan, banyak terkait dengan kebijakan tataguna tanah (Ruswandi, 2005). Menurut Kustiawan (1997), alih fungsi atau konversi lahan secara umum menyangkut transformasi dalam pengalokasian sumberdaya lahan dari satu penggunaan ke penggunaan lainnya. Alih fungsi lahan umumnya terjadi di wilayah sekitar perkotaan dan dimaksudkan untuk mendukung perkembangan sektor industri dan jasa. Dalam kegiatan alih fungsi lahan sangat erat kaitannya dengan permintaan dan penawaran lahan.

Adanya ketidakseimbangan antara penawaran dan permintaan dimana penawaran terbatas sedangkan permintaan tak terbatas menyebabkan alih fungsi lahan. Menurut (Barlowe, 1978), faktor faktor yang mempengaruhi penawaran lahan adalah karateristik fisik alamiah, faktor ekonomi, faktor teknologi, dan faktor kelembagaan. Selain itu, faktor-faktor yang mempengaruhi permintaan lahan adalah populasi penduduk, perkembangan teknologi, kebiasaan dan tradisi, pendidikan dan kebudayaan, pendapatan dan pengeluaran, selera dan tujuan, serta perubahan sikap dan nilai-nilai yang disebabkan oleh perkembangan usia. (Sumaryanto dan Tahlim, 2005) mengungkapkan bahwa pola konversi lahan dapat ditinjau dalam beberapa aspek. Pertama, alih fungsi secara langsung oleh pemilik lahan yang bersangkutan. Lazimnya motif tindakan ada 3: (a) untuk pemenuhan kebutuhan akan tempat tinggal, (b) dalam rangka meningkatkan pendapatan melalui alih usaha, (c) kombinasi dari (a) dan (b) seperti pembangunan rumah sekaligus dijadikan tempat usaha. Pola alih fungsi lahan ini terjadi disembarang tempat, kecil-kecil, dan tersebar. Dampak alih fungsi lahan dengan pola ini terhadap eksistensi lahan sawah sekitarnya baru significant untuk jangka waktu lama. Kedua, alih fungsi yang diawali dengan alih penguasaan lahan. Pemilik menjual kepada pihak lain yang akan memanfaatkannya untuk usaha nonpertanian atau kepada makelar. Secara empiris, alih fungsi lahan melalui cara ini terjadi dalam hamparan yang luas, terkonsentrasi, dan umumnya berkorelasi positif dengan proses urbanisasi (pengkotaan). Dampak alih fungsi lahan terhadap eksistensi lahan sawah sekitarnya berlangsung cepat dan nyata.

Alih fungsi lahan dapat bersifat permanen dan juga dapat bersifat sementara (Utomo, 1992). Jika lahan sawah beririgasi teknis berubah menjadi kawasan pemukiman atau industri, maka alih fungsi lahan bersifat permanen. Akan tetapi, jika sawah tersebut berubah menjadi perkebunan tebu, maka alih fungsi lahan tersebut bersifat sementara, karena pada tahun-tahun berikutnya dapat dijadikan sawah kembali. Alih fungsi lahan permanen biasanya lebih besar dampaknya dari pada alih fungsi lahan sementara.

Terkonsentrasinya pembangunan perumahan dan industri di Pulau Jawa menyebabkan terjadinya alih fungsi lahan. Di satu sisi alih fungsi lahan ini menambah terbukanya lapangan kerja di sektor non-pertanian seperti jasa konstruksi, dan industri, akan tetapi juga menimbulkan dampak negatif yang kurang menguntungkan. Menurut (Widjanarko, 2006) dampak negatif akibat alih fungsi lahan, antara lain:

1) Berkurangnya luas sawah yang mengakibatkan turunnya produksi padi, yang mengganggu tercapainya swasembada pangan.

2) Berkurangnya luas sawah yang mangakibatkan bergesernya lapangan kerja dari sektor pertanian ke nonpertanian, yang apabila tenaga kerja lokal yang ada tidak terserap seluruhnya justru akan meninggikan angka pengangguran. Dampak sosial ini akan berkembang dengan meningkatnya kecemburuan sosial masyarakat setempat terhadap pendatang yang pada gilirannya berpotensi meningkatkan konflik sosial.

3) Investasi pemerintah dalam pengadaan prasarana dan sarana pengairan menjadi tidak optimal pemanfaatannya.

4) Kegagalan investor dalam melaksanakan pembangunan perumahan maupun indusri sebagai dampak krisis ekonomi atau karena kesalahan perhitungan mengakibatkan tidak termanfaatkannya tanah yang telah diperoleh sehingga meningkatkan luas lahan tidur yang pada gilirannya akan menimbulkan konflik sosial seperti penjarahan tanah. 
5) Berkurangnya ekosistem sawah terutama di jalur pantai utara Pulau Jawa yang terbaik dan telah terbentuk puluhan tahun, sedangkan pencetakan sawah baru yang sangat besar biayanya di luar Pulau Jawa seperti di Kalimantan Tengah, tidak memuaskan hasilnya

Tanpa mempertimbangkan RTRW Kabupaten/Kota, lahan tersedia tersebut terdapat di kawasan budidaya pertanian atau di kawasan hutan. Pada kawasan pertanian, lahan tersedia dapat berupa padang alangalang/rumput, semak belukar, dan hutan sekunder. Pada kawasan hutan, lahan tersedia berupa hutan konversi dan hutan produksi yang secara hukum jika dibutuhkan dan disepakati dapat dijadikan sebagai lahan pertanian. Dari total luas lahan Indonesia yang berpotensi atau sesuai untuk pertanian (94,1 juta ha), sekitar 30,67 juta ha yang tersedia untuk perluasan areal pertanian (Tabel 4). Berdasarkan potensi dan kesesuaian biofisik, lahan tersedia tersebut terdiri atas lahan yang cocok untuk perluasan pertanian di lahan basah semusim (sawah) dengan luas 8,28 juta ha, untuk pertanian lahan kering tanaman semusim seluas 7,08 juta ha, dan untuk tanaman tahunan seluas 15,31 juta ha. Lahan basah untuk tanaman semusim terdapat pada lahan rawa dengan luas 2,98 juta ha (terutama di Papua) dan pada lahan non-rawa seluas 5,30 juta ha. Lahan kering potensial tersedia terdiri atas tanah mineral (non-gambut) seluas 19,16 juta ha dan tanah gambut potensial seluas 3,23 juta ha. (Las \& Mulyani., 2009) melaporkan bahwa sebagian besar lahan tersedia tersebut berada di kawasan budidaya hutan (hutan produksi dan konversi), yaitu 20,4 juta ha (66,4\%), sisanya 10,3 juta ha $(33,6 \%)$ berada di kawasan budidaya pertanian. Hal ini menunjukkan bahwa kebutuhan lahan untuk perluasan areal pertanian di masa yang akan datang harus dipenuhi dari lahan kawasan hutan.

\section{Intensifikasi Lahan Pertanian}

Giller et al. (1997) Seperangkat pola perubahan penggunaan lahan dengan fitur umum peningkatan penggunaan sumber daya yang sama untuk produksi pertanian, biasanya sebagai hasil dari beralih dari intermiten menjadi budidaya berkelanjutan dari lahan yang sama. Intensifikasi pertanian adalah sistem produksi yang secara konvensional dicirikan oleh rendah mengikuti rasio dan penggunaan input secara intensif, seperti modal, tenaga kerja, pestisida, dan bahan pupuk kimia, untuk meningkatkan hasil pertanian, sehingga meningkatkan pendapatan petani dan mengurangi kemiskinan.

Namun tetap menjadi pertanyaan, apakah intensifikasi semacam itu dapat menyelaraskan produksi pangan dan perlindungan lingkungan. Studi sebelumnya menunjukkan bahwa produksi pertanian intensif telah menyebabkan peningkatan erosi, kesuburan tanah yang lebih rendah, dan berkurangnya keanekaragaman hayati (Matson et al. 1997). Intensifikasi dapat menyebabkan konversi lahan marginal, seperti padang rumput atau berbagai lahan, untuk dipangkas produksi, menyebabkan degradasi lahan (Li et al., 2013). Intensifikasi mungkin juga negatif eksternalitas regional karena penggunaan air dan limpasan bahan kimia dapat mempengaruhi area di luar itu sebenarnya dibudidayakan (Matson et al., 1997; Tilman et al., 2002). Intensifikasi pertanian yaitu pengolahan lahan pertanian yang ada dengan sebaik-baiknya untuk meningkatkan hasil pertanian dengan menggunakan berbagai sarana. Ekstensifikasi pertanian adalah usaha meningkatkan hasil pertanian dengan cara memperluas lahan pertanian baru, misalnya membuka hutan dan semak belukar, daerah sekita rawa-rawa, dan daerah pertanian yang belum dimanfatkan.

Usaha-usaha meningkatkan hasil pertanian dapat dilakukan antara lain dengan cara membangun gudanggudang, pabrik penggilingan padi dan menetapkan harga dasar gabah, memberikan berbagai subsidi dan insentif modal kepada para petani agar petani dapat meningkatkan produksi pertaniannya, menyempurnakan sistem kelembagaan usahatani melalui pembentukan kelompoktani dan Koperasi Unit Desa (KUD) di seluruh pelosok daerah yang bertujuan untuk memberikan motivasi produksi dan mengatasi hambatanhambatan yang dihadapi para petani.

Usaha peningkatan produksi bahan pangan dan produk pertanian lainnya mutlak diperlukan, seiring dengan meningkatnya jumlah penduduk dan persaingan ekonomi global. Hal ini memerlukan upaya yang terintegrasi dalam meningkatkan produksi komoditas pertanian prospektif yang berorientasi agribisnis dengan menawarkan kesempatan kepada para investor untuk mengembangkan usaha dan sistem agribisnis yang berkelanjutan. Salah satu informasi dasar yang dibutuhkan adalah data sumberdaya lahan yang berasal dari peta potensi sumberdaya lahan, dimana informasi tersebut memberikan gambaran tentang luasan, distribusi, tingkat kesesuaian lahan, faktor pembatas, dan alternatif teknologi yang dapat diterapkan. Dengan tersedianya informasi potensi sumberdaya lahan, maka pengembangan berbagai komoditas pertanian dapat disesuaikan dengan potensi sumberdaya lahannya, sehingga membantu upaya peningkatan produksi komoditas pertanian yang bersangkutan.

Dalam tulisan ini akan dibahas potensi sumberdaya lahan pertanian di Indonesia, pada perkembangan dan penggunaan lahan yang terjadi pada sistem pertanian terpadu pada daerah-daearah pertanian dengan lahan 
yang luas di indonesia pada saat dulu dan sekarang., permasalahan pemanfaatan yang dihadapi, dan upayaupaya strategi yang perlu diperhatikan agar pemanfaatan lahan lebih optimal yaitu dengan sistem tanaman terpadu.

\section{Rumusan Masalah Penulisan Paper}

Praktek budidaya pertanian tidak jarang menimbulkan dampak negatif yang menyebabkan lahan terdegradasi. Dua faktor penting dalam usaha pertanian yang potensial menimbulkan dampak pada sumberdaya lahan adalah tanaman dan manusia (sosio kultural) yang menjalankan pertanian. Diantara kedua faktor tersebut, faktor manusialah yang berpotensi menimbulkan dampak positif atau negatif terhadap lahan, tergantung bagaimana cara menjalankan pertanian tersebut. Kegiatan atau cara budidaya pertanian yang potensial menimbulkan dampak negatif antara lain pengolahan tanah, penggunaan agro-kimia yang tidak ramah lingkungan (pupuk dan insektisida), serta sistem budidaya. Beranjak dari penjelasan latar belakang, dapat diidentifikasi sebuah masalah yaitu bagaiman mengintensifkan lahan pertanian yang sudah ada dengan cara penerapan sistem pertanian terpadu, agar tidak terjadi peningkatan alih fungsi lahan.

\section{Tujuan dan Manfaat Penulisan Paper}

Bertujuan untuk melihat dan mengumpulkan informasi tentang potensi lahan yang belum termanfaatkan secara optimal pada penerapan sistem pertanian terpadu. Intensifikasi pertanian yang merupakan pengolahan lahan pertanian yang ada dengan sebaik-baiknya untuk meningkatkan hasil pertanian dengan menggunakan berbagai sarana dan sistem pertanian berkelanjutan dapat diwujudkan

\section{METODE}

Penelitian tentang tinjauan konsep dan sejarah perkembangan serta pelaksanaaan sistem pertanian terpadu keuntungan serta kendala-kendala yang terjadi dalam pelaksanaan sistem pertanian terpadu di beberapa negara dan di Indonesia. Penelitian dilakukan dengan metode studi literatur melalui penelaahan perkembangan sistem pertanian terpadu melalui jurnal-jurnal terkait.

Metode penelitian dilakukan dengan cara studi literatur yaitu menganalisa perkembangan sistem pertanian terpadu, keuntungan serta kendala-kendala yang terjadi dalam pelaksanaan sistem pertanian terpadu. Sedangkan data yang dikumpulkan adalah data sekunder dan diolah dari jurnal-jurnal terkait sistem pertanian terpadu di Indonesia. Untuk memperoleh data sekunder berasal dari jurnal-jurnal terkait dengan sejarah perkembangan serta penerapan pelaksananaan sistem pertanian terpadu keuntungan serta kendala-kendala yang terjadi dalam pelaksanaan. Data yang dikumpulkan meliputi konsep pertanian terpadu secara umum, Keuntungan pelaksanaan pertanian terpadu, Kendala-kendala pertanian terpadu dalam pelaksanaan, serta solusi dari pemecahan kendala-kendala dalam pelaksanaan dari penerapan sistem pertanian. Data dan informasi yang terkumpul kemudian divalidasi, dianalisis serta diinterpretasikan. Analisis data dan informasi bersifat deskriptif dan eksplanatory. Analisis deskriptif dimaksudkan untuk menjelaskan fenomenafenomena konsep serta keunggulan dan kekurangan yang terjadi dalam penerapan pelaksanaan sistem pertanian terpadu..

\section{HASIL DAN PEMBAHASAN}

\section{Strategi Pemanfaatan Lahan}

Untuk menjaga agar terjadi keseimbangan antara kebutuhan lahan untuk pangan dan non pangan, perlu strategi dan upaya pemanfaatan sumberdaya lahan yang meliputi: 1. Pemanfaatan sumberdaya lahan potengillersial tersedia untuk perluasan areal pertanian harus sesuai dengan peruntukkannya. Kawasan yang diarahkan untuk pertanian lahan basah dan lahan kering tanaman pangan semusim harus dimanfaatkan untuk tanaman semusim (pangan dan hortikultura). Komoditas bioenergi non pangan dan perkebunan lainnya diarahkan pada lahan kering potensial untuk tanaman tahunan. 2. Alih fungsi lahan dari lahan pertanian produktif ke non pertanian dan alih fungsi lahan dari lahan tanaman pangan ke non pangan (perkebunan) perlu dihindari, antara lain dengan adanya sistem insentif bagi petani yang bergerak di bidang pertanian tanaman pangan. Selain itu, perlu adanya percepatan penyiapan dukungan kebijakan yang berkaitan dengan pelaksanaan Reforma Agraria. 3. Optimalisasi pemanfaatan sumberdaya lahan yang ada melalui peningkatan produktivitas, dan pengembangan inovasi teknologi yang lebih mengutamakan kelestarian sumberdaya alam dan lingkungan. Selain itu, perlu adanya diversifikasi pertanian dan percepatan pengembangan potensi genetik dan teknologi produksi tanaman bioenergi non pangan. 4. diperlukan penggabungan dua sistem 
usaha tani (terpadu) agar lahan dapat dimanfaatkan secara oprimal (intensif). 5. Percepatan penelitian dan pengembangan serta re-evaluasi lahan tersedia dan lahan terlantar yang sudah dilepas.

\section{Pentingnya intensifikasi lahan pada sistem pertanian terpadu}

Untuk itu diperlukan penggabungan dua sistem usaha tani (terpadu) agar lahan dapat dimanfaatkan secara optimal (intensif). Sistem pertanian terpadu adalah sistem pertanian yang mengkombinasikan dua atau lebih bidang pertanian (Channabasa-vanna, 2009; Ugwumba, Okoh, Ike, Nnabuife and Orji, 2010), menggunakan konsep daur ulang biologis dan terdapat hubungan input outputantar komoditi. Kehadiran sapi liar di perkebunan kelapa sawit pada umumnya dianggap sebagai masalah serius karena mereka menghabiskan banyak daun dan mengunyah tandan buah, dan juga pemadatan tanah / kerusakan drainase. Namun, dampak negatif ternak terhadap perkebunan kelapa sawit hanya terjadi pada situasi dimana tidak ada kontrol yang tepat terhadap hewan. Kerapatan tebar dan penggembalaan yang tinggi untuk waktu yang lama di daerah yang sama akan mengakibatkan penurunan hasil panen. Ada 60 sampai 70 jenis tanaman penutup kacang tanah yang ditanam, tumbuh secara alami, daun dan pakis yang luas, yang dapat dianggap sebagai pakan ternak. Dalam praktek agronomi pertanian yang normal, spesies ini akan berkurang menjadi sekitar 20 saat pohon palem tumbuh lebih tua. Kekurangan tenaga kerja dan kenaikan biaya tenaga kerja merupakan masalah serius dari sektor perkebunan. Dalam kondisi yang tepat, ternak dapat digunakan secara efektif untuk mengendalikan gulma. Pengelolaan ternak yang tepat di perkebunan kelapa sawit dengan penggunaan herbisida selektif minimal dapat mengakibatkan perkebunan menjadi lebih ramah lingkungan dan menjamin pembangunan sumber daya yang berkelanjutan. Bekerja pada pengendalian biologis gulma dalam sistem pengelolaan hama kelapa sawit terpadu telah berkonsentrasi pada penggunaan serangga dan patogen tanaman spesifik. Pendekatan ekologis untuk pengendalian gulma adalah memastikan bahwa tanaman inang bekerja dengan alam dan tidak melawannya. Penggunaan ternak sebagai agen biologis untuk pengendalian gulma di perkebunan kelapa sawit memungkinkan terbentuknya hubungan yang harmonis antara ternak, semak-semak dan pohon kelapa sawit. Teknik ini terus diadopsi dan disempurnakan dan pendekatan holistik adalah kunci keberhasilan sistem.

Sementara spesialisasi telah mengakibatkan rendahnya harga pangan dan peningkatan aksesibilitas makanan yang dulu mahal seperti daging, juga menyebabkan biaya masyarakat dan lingkungan seperti polusi udara dari umpan, kontaminasi saluran air dengan sedimen, dan konsentrasi pupuk yang bermasalah di daerah lokal (Matson et al., 1997). Salah satu alternatif untuk spesialisasi adalah pertanian tanaman pangan / peternakan terpadu, praktik pengelolaan tanaman pangan dan hewan di satu peternakan. Studi dan ulasan telah menunjukkan bahwa pertanian terpadu dapat meningkatkan produksi tanaman pangan dan ekonomi pertanian.

\section{Masalah-masalah yang terjadi pada lahan dalam sistem pertanian terpadu}

Selanjutnya Conway (1986) menjelaskan bahwa pihak pengelola perkebunan kelapa sawit juga harus memperhatikan konservasi lahan dan menghindari erosi sesuai dengan ketentuan yang berlaku. Pengelola perkebunan berkewajiban untuk melakukan konsevasi kawasan dengan potensi erosi yang tinggi serta mengelola perkebunan dengan erosi tinggi sebaik mungkin sehingga tidak menimbulkan erosi..

\section{KESIMPULAN}

Pertanian terpadu memberi kontribusi penting bagi pembangunan yang sesuai dengan pertimbangan pertimbangan ekonomi, ekologi dan sosial untuk mewujudkan bisnis penting produksi pangan pertanian. Pada akhirnya sistem pertanian terpadu yang dilaksanakan pada suatu usaha akan memperoleh keuntungan, menyatakan bahwa terdapat delapan keuntungan dari penerapan pola sistem integrasi tanaman-ternak, yaitu: Diversifikasi penggunaan sumber daya produksi, mengurangi terjadinya risiko usaha, efisiensi penggunaan tenaga kerja, efisiensi penggunaan input produksi, mengurangi ketergantungan energi kimia dan biologi serta masukan sumber daya lainnya, sistem ekologi lebih lestari serta tidak menimbulkan polusi sehingga ramah lingkungan, meningkatkan output, dan mampu mengembangkan rumah tangga petani yang berkelanjutan.

\section{DAFTAR PUSTAKA}

Puslittanak, P.P. 2003. Atlas Sumberdaya Lahan Eksplorasi Indonesia. Bogor: Pusat Penelitian Tanah dan Agroklimat.

Arsyad. 1989. Konservasi tanah dan air. Bogor: IPB Press.

Balai Besar Penelitian dan Pengembangan. 2008. Inovasi Teknologi Pertanian. Kementrian Pertanian. Jakarta. 
Barlowe, R. 1978. Land Resource Economics. Englewood Cliffs, N. J: Prentice Hall Inc.

Channabasavanna, A.S., D.P. Biradar, K.N. Prabhudev, and M. Hegde. 2009. Development of Profitable Integrated Farming System Model for Small and Medium Farmers of Tungabhadra Project Area of Karnataka. Karnataka Journal of Agriculture Science 22(1): 25-27.

Giller, K., M.H. Beare, P. Lavelle, A.M.N. Izac, and M.J. Swift. 1997. Agricultural Intensification, Soil Biodiversity and Agroecosystem Function. Applied Soil Ecology 6(1): 3-16.

Hidayat, A., dan A. Mulyani. 2002. Lahan Kering untuk Pertanian. Dalam Teknologi Pengelolaan Lahan Kering. Pusat Penelitian dan Pengembangan Tanah dan Agroklimat. Badan Litbang Deptan. Bogor.

Hikmatullah, A., dan Hidayat. 2007. Tinjauan Pemetaan Sumber Daya Tanah di Indonesia: Strategi Penyelesaian dan Alternatif Teknologinya. Jurnal Sumberdaya Lahan 1(3): 43-56.

Kustiawan, I. 1997. Konversi Lahan Pertanian di Pantai Utara dalam Prisma No.1. Jakarta: Pustaka LP3ES.

Las, I., dan A. Mulyani. 2009. Sumber Daya Lahan Potensial Tersedia untuk Mendukung Ketahanan Pangan dan Energi. Semiloka Nasional Strategi Penanganan Krisis Sumber Daya Lahan untuk Mendukung Kedaulatan Pangan dan Energi. (hal. 64-74). Bogor: IPB.

Matson., P.A., W.J. Parton, A.G. Power, and M.J.Swift. 1997. Agricultural Intensification and Ecosystem Properties. Science 277:504-509.

Ruswandi, A. 2005. Dampak Konversi Lahan Pertanian Terhadap Perubahan Kesejahteraan Petani dan Perkembangan Wilayah. Tesis. Institut Pertanian Bogor. Bogor.

Sitorus, S.R. 2004. Evaluasi Sumberdaya Lahan. Bandung: Tarsito.

Sumaryanto, dan S. Tahlim. 2005. Pemahaman Dampak Negatif Konversi Lahan. Prosiding. Pusat studi Pembangunan Pertanian dan Pedesaan LPPM IPB. Bogor.

Tilman, D., K. Cassman, P.A. Matson, and R. Naylor. 2002. Review Article Agricultural Sustainibility and Intensive Production Practices. Nature: 418(6898): 671-677.

Ugwumba, C.O.A., R.N. Okoh, P.C. Ike, E.L.C. Nnabuife, and E.C. Orji. 2010. Integrated Farming System and its Effect on Farm Cash Income in Awka South Agricultural Zone of Anambra State, Nigeria. American-Eurasian J. Agric. And Environ. Sci 8(1): 1-6.

Utomo. 1992. Alih fungsi Lahan: Tinjauan Analitis Makalah Seminar Pembangunan dan Pengendalian Alih Fungsi Lahan. Universitas Negeri Lampung. Lampung.

Widjanarko, E.A. 2006. Aspek Pertahanan Dalam Pengendalian Alih Fungsi Lahan pertanian (sawah). Prosiding Seminar Nasional Multifungsi Lahan Sawah (hal. 22-23). Jakarta: Pusat Penelitian dan Pengembangan BPN. 